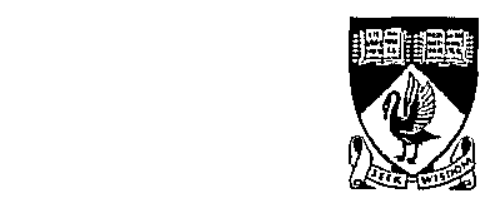

FUTURE TRENDS IN JAPANESE STEEL CONSUMPTION

by

Paul Crompton

DISCUSSION PAPER 99.10

DEPARTMENT OF ECONOMICS

THE UNIVERSITY OF WESTERN AUSTRALIA

NEDLANDS, WESTERN AUSTRALIA 6907 


\title{
FUTURE TRENDS IN JAPANESE STEEL CONSUMPTION
}

\author{
by \\ Paul Crompton \\ Department of Economics \\ University of Western Australia
}

DISCUSSION PAPER 99.10

DEPARTMENT OF ECONOMICS

THE UNIVERSITY OF WESTERN AUSTRALIA

NEDLANDS, WESTERN AUSTRALIA 6907

ISSN 0811-6067

ISBN 0-86422-917-8 


\title{
FUTURE TRENDS IN JAPANESE STEEL CONSUMPTION
}

\begin{abstract}
This paper uses an intensity of use model to forecast crude steel consumption in Japan over the period 1997-2005. Six steel consuming industries are identified; Machinery, Electrical Machinery and Equipment, Transport Equipment, Other Manufacturing, Construction and Fabricated Metal Products. The model decomposes changes in steel consumption for each industry into three components: (i) changes in the steel intensity of production in each steel consuming industry, (ii) changes in the size of these industries relative to aggregate domestic production and (iii) the rate of growth in $G D P$. Forecasts of these separate components for the six steel consuming industries are then used to forecast aggregate steel consumption.

The results suggest that crude steel consumption in Japan will fall from 86 million tonnes in 1997 to around 76.5 million tonnes in 2005 . The cause of this reduction in consumption is low GDP growth and further reductions in the steel intensity of Japanese production over the forecast period. An interesting finding of this paper is that cyclical increases in investment expenditure in Japan appear to lead to significant rises in the steel intensity of domestic production, and hence steel consumption.
\end{abstract}




\section{INTRODUCTION}

Since the early 1970's, Japan has been one of the largest consumers of crude steel in the world and an extremely important market for Australian, and more recently Brazilian, iron ore exports. Today, the future of Japan's steel industry remains in doubt. Crude steel consumption in Japan has fallen from 99 million tonnes in 1990 to 86 million tonnes in 1997, with a concomitant reduction in iron ore import volumes and prices. An important issue is whether this fall in consumption represents a cyclical downturn or a more permanent change reflecting fundamental structural adjustments in the composition of domestic production in Japan. For certain, any continuation of this trend will force Japan's iron ore suppliers to seek new markets.

This paper will use the intensity of use technique to uncover the causes of the recent fall in crude steel consumption in Japan and, based on these findings, forecast consumption to 2005. Six steel consuming industries are identified; Machinery, Electrical Machinery and Equipment, Transport Equipment, Other Manufacturing, Construction and Fabricated Metal Products. Under the approach used in this paper, steel consumption in each industry is decomposed into three fundamental determinants: (i) the average quantity of steel used per unit of output, (ii) industry output relative to gross domestic product and (iii) gross domestic product. Forecasts of these determinants for each industry are then used to construct industry and aggregate steel consumption forecasts.

By disaggregating the analysis in this manner, we can separately examine the determinants of crude steel consumption in each industry. This is an important contribution since the results suggest that these determinants have changed at significantly different rates across the six industries. Furthermore, it permits us to more readily identify which steel consuming industries are most responsible for the recent downturn in steel consumption and the likelihood of a continuation of this trend.

The results suggest that crude steel consumption in Japan will fall from 86 million tonnes in 1997 to around 76.5 million tonnes by 2005. The cause of this fall in consumption is low GDP growth and further reductions in the steel intensity of Japanese domestic production over the forecast period. There is little evidence to suggest that the recent falls in consumption are cyclical downturns. The results have important implications for iron ore suppliers to Japan who can expect to face lower export volumes 
as well as downward pressure on iron ore prices over the medium term. It appears that only the resumption of GDP growth of around 2-3 per cent in Japan early in the next century can stem this trend.

\section{STEEL CONSUMPTION IN JAPAN}

Japan's consumption of crude steel increased from 4.1 Mt (million tonnes) in 1950 to 86.0 Mt in 1997 (see Figure 1). During the first half of this period, 1950-73, consumption increased to $87.2 \mathrm{Mt}$, representing an average annual growth rate of 15.8 per cent. During the second period from 1974 onwards, however, consumption remained largely unchanged with an average annual growth rate of only 0.2 per cent. The slowdown in the growth of crude steel consumption after 1973 was not unique to Japan. Tilton (1990) found that growth in steel consumption was stagnant in this period in the majority of OECD countries.

FIGURE 1

CRUDE STEEL CONSUMPTION IN JAPAN 1950-97

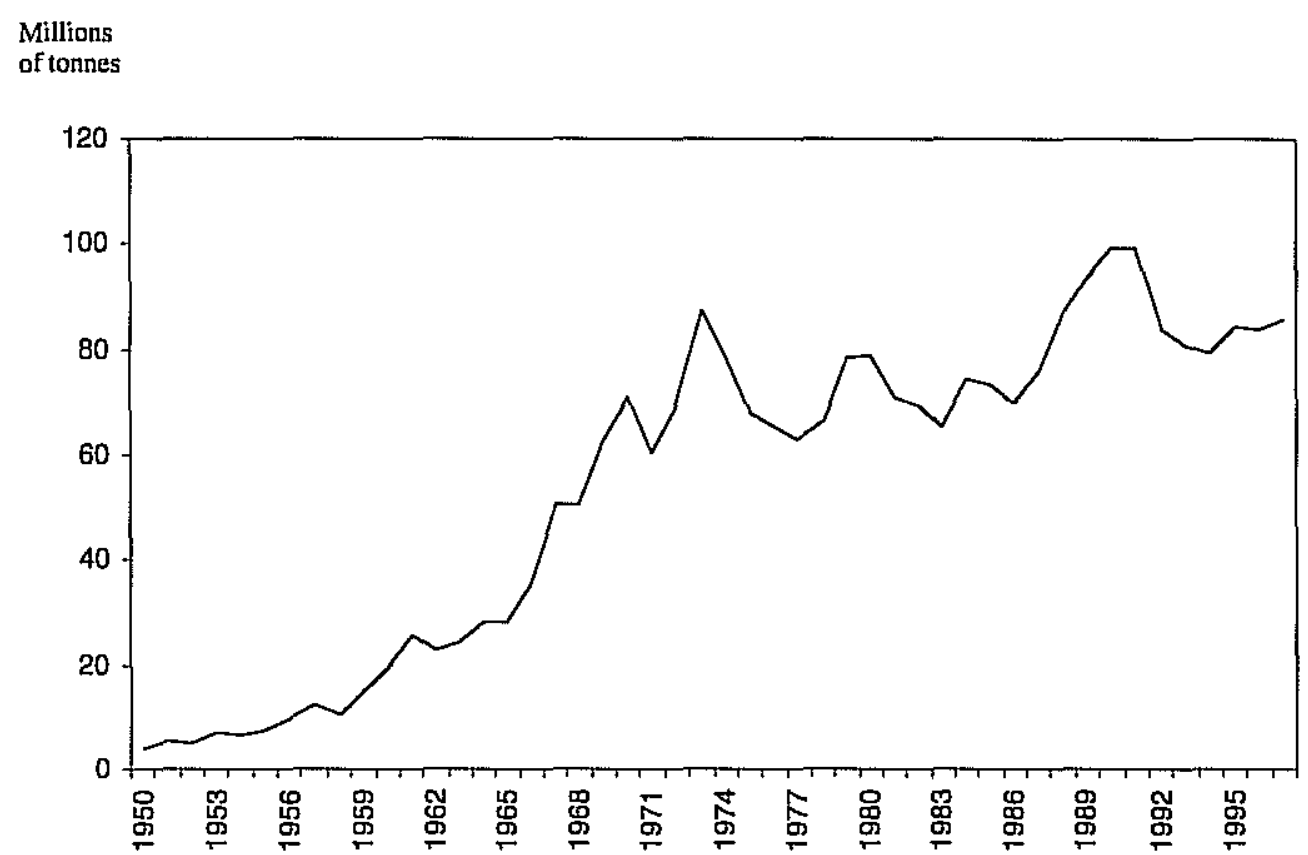

Source: International Iron and Steel Institute (1998 and earlier issues) 
FIGURE 2

GROSS DOMESTIC PRODUCT GROWTH IN

JAPAN 1950-97

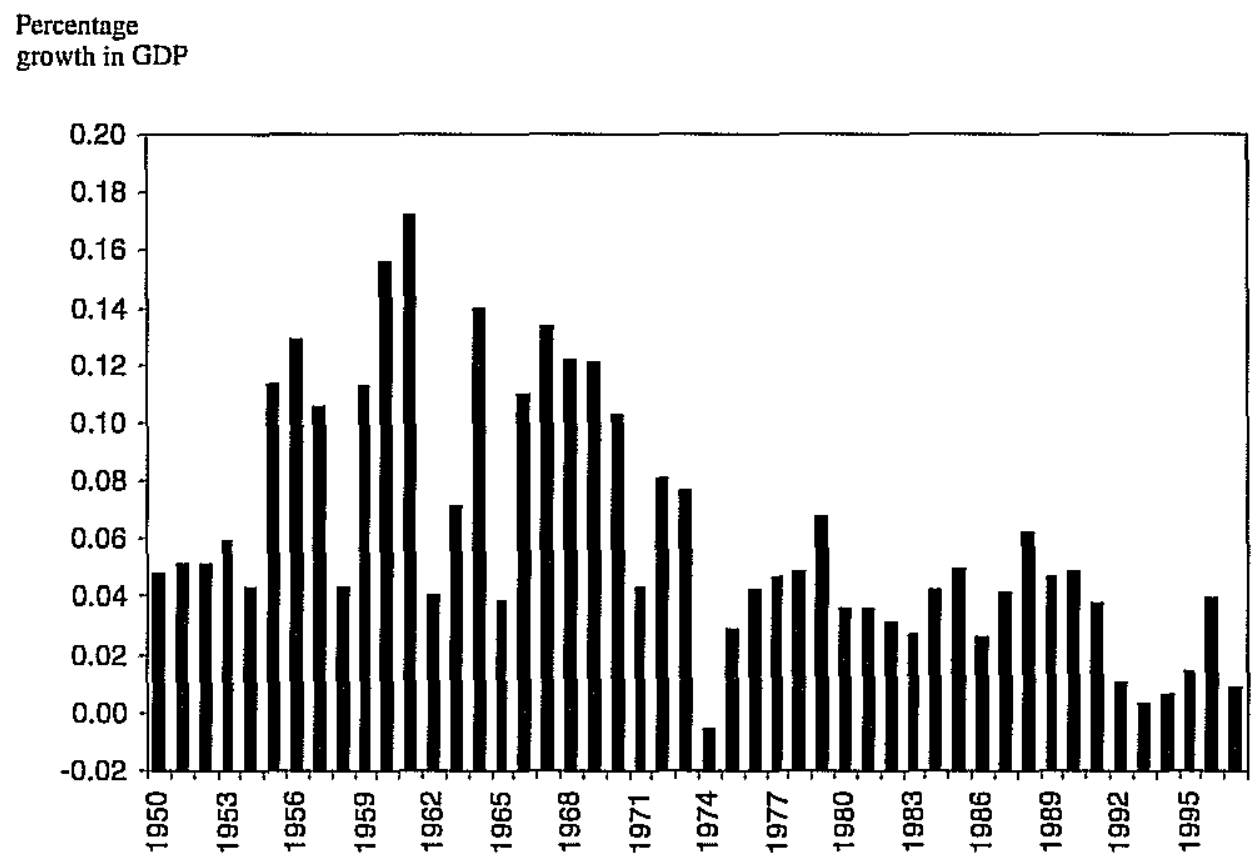

Source: International Monetary Fund (1998 and earlier issues)

The stagnation of Japanese crude steel consumption after 1973 is attributable to two factors. First, GDP growth over the period 1974-97 slowed to an average annual rate of 3.4 percent (see Figure 2). Second, the intensity of steel use (defined as tonnes of steel consumed per unit of GDP) over this same period reversed its previous upward trend and in 1997 had returned to levels close to that of 1950 (see Figure 3). Hence, over this latter period, not only had the rate of increase in the size of the economy slowed markedly, but the physical quantity of steel consumed per unit of GDP had fallen also.

Figures 2 and 3 also reveal the cause of the 13 per cent fall in crude steel consumption since 1990. Growth in GDP slowed to an annual average rate of 2.1 per cent over the period 1990-97. Over the same period, steel intensity fell by 23 per cent, indicating that lower steel intensity was primarily responsible for the fall in steel consumption. 
FIGURE 3

INTENSITY OF CRUDE STEEL USE IN JAPAN 1950-97

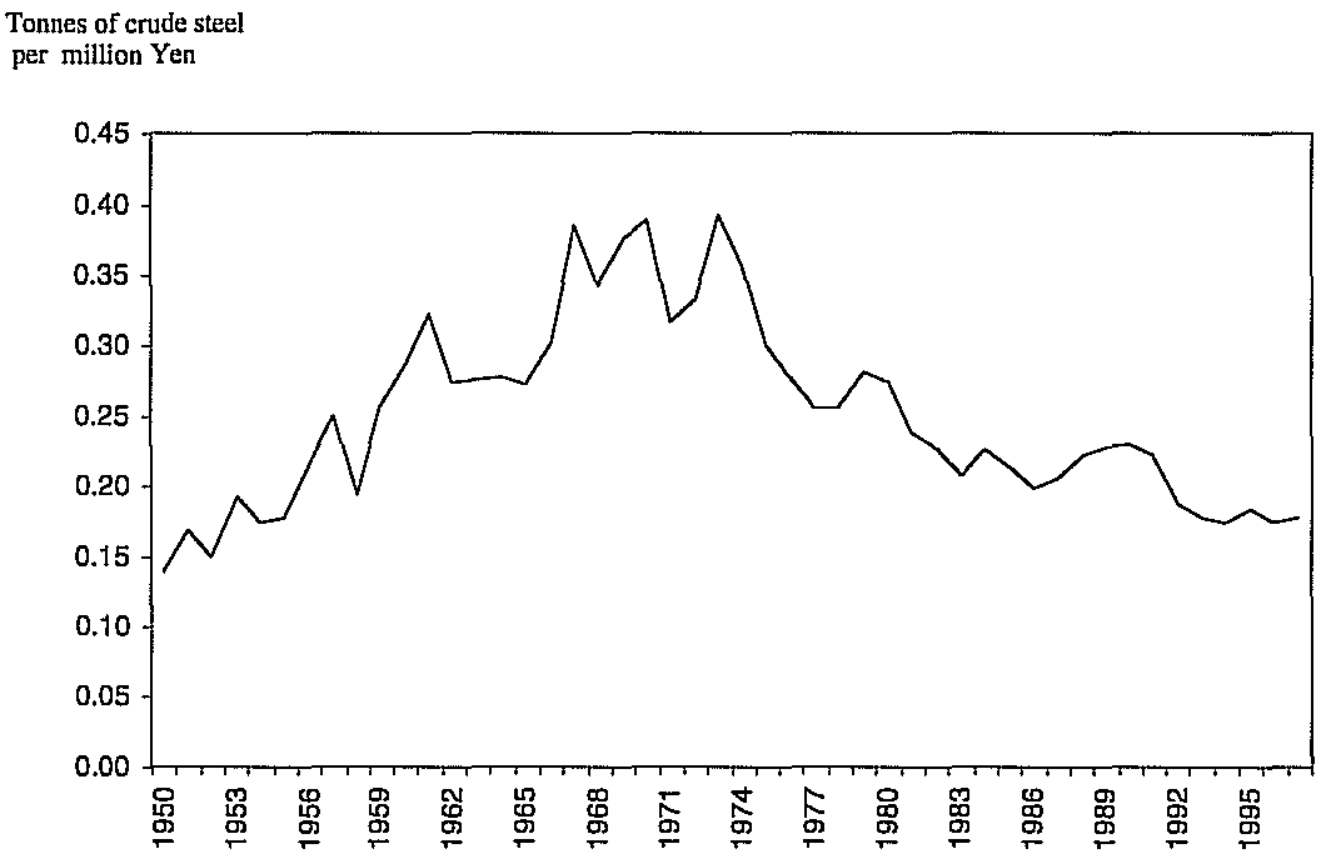

\section{PREVIOUS STUDIES}

Several approaches have been used to forecast steel consumption. The first and most traditional approach uses econometric demand equations that model steel consumption primarily as a function of industrial production or some other broader measure of economic activity such as gross domestic product (GDP). Labson, Gooday and Manson (1995), for example, use a dynamic, non-spatial, partial-equilibrium world iron ore and steel trade model to forecast crude steel consumption in the world's major steel consuming regions, including Japan, China and North America. Under this approach, crude steel consumption is forecast for each region of the model using a single linear econometric equation, which explains variations in consumption using an index of steel prices, industrial production and a time trend as a measure of technological change.

The estimation of a vector autoregression is another approach that has been used to forecast steel consumption. This method uses the historical correlations between variables in a system of dynamic, linear equations to extrapolate future values of all 
variables. Chen, Clements, Roberts and Weber (1991) use this approach to forecast crude steel consumption in China, while Wu (1998) implements an identical approach to update these forecasts. Both models incorporate Bayesian priors on the coefficients in the system of equations, which allows the modeller to enforce a priori restrictions on these coefficients. Crompton (1998) went one step further by pre-determining the time path of $G D P$ growth over the forecast period for the countries of South-East Asia. By doing so, the impact of the Asian financial crisis of $1997 / 98$ on future GDP growth can be incorporated directly into the forecasting exercise.

The third approach to forecasting steel consumption is the intensity of use technique. One major advantage of this approach is the disaggregated nature of the analysis in which steel consumption is modelled for different end use industries. Roberts (1990), for example, uses this approach to forecast steel consumption in the United States over the period 1984 to 2010 , by disaggregating total steel consumption into the quantities consumed in each of the machinery, transport and infrastructure industries. By doing this, trends in steel consumption in each end-use industry relative to total industry output can be established, as well as changes in the size of these industries relative to the total GDP.

\section{AN INTENSITY OF USE MODEL FOR JAPAN}

This paper follows the intensity of use model developed by Roberts (1990). In this model, steel consumption is disaggregated by end-use industry, such that in the general specification presented below, there are $n$ steel consuming industries. Steel consumption in each of these $n$ industries is decomposed into three main components. The identity on which the intensity of use model is based is:

$$
S_{t}=\sum_{i=1}^{n} \frac{S_{i t}}{P_{i t}} \times \frac{P_{i t}}{G D P_{t}} \times G D P_{t}
$$

or

$$
S_{t}=\sum_{i=1}^{n} M C P_{i t} \times P C I_{i t} \times G D P_{t}
$$


or

$$
S_{t}=I U_{t} \times G D P_{t}
$$

where $S_{i t}$ is the quantity of steel consumed by industry $i, S_{t}$ is the quantity of steel consumed across all $n$ steel consuming industries, $P_{i t}$ is the total value of production in industry $i$ and $I U_{t}=S_{t} / G D P_{t}$ is the average intensity of steel use across the $n$ steel consuming industries. The $M C P_{i t}$ is the material composition of product for industry $i$, which measures the average quantity of steel used per unit of output in that industry. The $P C I_{i t}$ is the product composition of income for industry $i$ which measures the relative share of that industry's production in GDP. Multiplying these three components of steel consumption in any particular time period for industry $i$ yields steel consumption in that industry. Addition of these industry sub-totals gives total domestic steel consumption. Forecasts of these separate components for each industry are used to forecast aggregate steel consumption.

The specification presented in equation (1) is unsuitable for forecasting steel consumption in countries that are heavily dependent upon international trade in steel intensive products. The problem lies in the definition of $P C I$ and the subsequent difficulty in forecasting this variable since it may not necessarily be correlated with per capita income levels as suggested by the intensity of use hypothesis. If $P C I$ is measured in this way, it will include exported goods (which are not influenced by changes in domestic per capita income levels) and exclude imported goods (which are influenced by changes in domestic per capita income levels). To develop an open economy version of this technique we must modify the definitions of $M C P$ and $P C I$ presented above.

In the open economy version of the intensity of use model, the definition of $M C P$ remains largely unchanged. It is expressed as:

$$
M C P_{i t}=\frac{S_{i t}}{P D_{i t}+P X_{i t}}
$$


This definition is identical to that used in the closed economy model of equation (1), the only difference being that domestic production in each industry has been separated according to final marketplace destination.

In the open economy model, $P C I$ must be adjusted to take into account the effect of net trade. To make the adjustment, we separate goods from industry $i$ into domestically produced goods $(P D)$ and imported goods $(P I)$. The $\mathrm{PCI}$ can now be expressed as:

$$
P C I_{i t}=\frac{P D_{i t}+P I_{i t}}{G D P_{i t}}
$$

Equation (1) can be used to forecast steel consumption for each of the $i$ industries once it has been adjusted for changes made to $P C I$ in equation (3). The need for this adjustment arises since domestically produced goods that are exported are not included in the open economy $P C I$ measure, while imported goods are included. Hence the quantity of steel used in these exported goods must be added to the steel used in domestically produced and consumed goods, while the quantity of steel contained in imported goods must be subtracted.

If we define $P N X_{i t}=P X_{i t}-P I_{i t}$ as net exports of goods from industry $i$ during period $t$, then the quantity of steel contained in these goods is $M C P_{i t} \times P N X_{i t}$. If this figure is positive, then the quantity of steel contained in exports is larger than the quantity contained in imports and the open economy $P C I$ will underestimate the quantity of steel consumed by the $i^{\text {th }}$ industry. The following equation incorporates these adjustments:

$$
S_{t}=\sum_{i=1}^{n} M C P_{i t} \times P C I_{i t} \times G D P_{t}+M C P_{i t} \times P N X_{i t}
$$

where $M C P_{i t}$ and $P C I_{i t}$ are defined according to equations (2) and (3) respectively. Equation (4) shows that the four determinants of steel consumption are $M C P, P C I, P N X$ and GDP. It is important to realise that the right side of equations (1) and (4) are mathematically equivalent. 


\section{EXPLAINING THE DETERMINANTS OF STEEL CONSUMPTION}

In this section we define the equations used to forecast $M C P, P C I$ and $P N X$. Where possible, the economic variables most responsible for change in these components of aggregate steel consumption are included in the forecasting equations. The inclusion of explanatory variables will be kept to a minimum. The reason being that for each explanatory variable included in the forecasting equation we incur the additional complication of requiring forecasts of that variable over the forecast period.

\section{The Material Composition of Products}

Changes in $M C P$ over time reflect two factors. First, the impact of new resource saving technologies such as advances in the manufacturing process and product design. Second, material substitution caused by changes in relative input prices or by improvements in material characteristics.

The uncertain impact of technological change and the difficulty in forecasting material substitution makes the task of forecasting $M C P$ difficult using sound rationale. In modelling $M C P$, it is unclear how to measure the rate of technological change, the impact it has on steel demand, precisely how relative material price changes influence steel consumption, which steel price series to use and the impact of changes in material characteristics. Given the difficultly in measuring and separately identifying the fundamental economic forces that drive $M C P$, we assume that changes in $M C P$ are best approximated by a time trend. The general form of the equation used to forecast $M C P$ is:

$$
M C P_{i t}=\phi_{i}+\rho_{i} T_{t}
$$

where $\phi_{i}$ is a constant term, $\rho_{i}$ measures the rate at which $M C P$ changes over time in the $i_{t h}$ industry and $T_{t}$ is a time trend. Various other specifications of this equation are possible. The most useful alternative is the linear-log time trend in which the final term in equation (5) is replaced with $\rho_{i} \ln \left(T_{i}\right)$. As demonstrated in the following chapter, this type of specification proves to be an extremely close approximation to the actual rate of change in $M C P$ across four of the six steel consuming industries in Japan. 


\section{The Product Composition of Income}

The $P C I$ measures consumer preferences for the goods produced in a particular industry relative to all other goods and services. Consumer preferences, and hence $P C I$, will adjust over time as per capita income changes. This adjustment will take place in two ways. First, changes in the composition of domestic expenditure, facilitated by long term rises in per capita income, will lead to the gradual rise of certain industries such as services and high technology and the gradual decline of other industries such as agriculture. Second, short term fluctuations in per capita income will cause temporary adjustments in consumer expenditure patterns which in turn affect the $P C I$ of all industries.

To incorporate these influences, $P C I$ is modelled using a consumption function relationship. This approach assumes that consumer demand for the output of a particular industry depends upon (i) current per capita income and (ii) deviations in per capita income from previous levels. The consumption function for output from industry $i$ can be written on a per capita basis as:

$$
\frac{P D_{i t}+P I_{i t}}{P O P_{t}}=\alpha_{i}+\beta_{i} Y_{t}+\delta_{i} \operatorname{dev} Y_{t}
$$

where $P O P_{t}$ is population, $Y_{t}$ is per capita income and $\operatorname{dev} Y_{t}$ is the deviation of current per capita income from trend per capita income, such that:

$$
\operatorname{dev} Y_{t}=\text { current } Y_{t}-\text { trend } Y_{t}
$$

where trend $Y_{t}$ is measured using a simple linear trend in $Y_{t}$ over the sample and forecast periods.

To obtain a forecasting equation for $P C I$ we divide equation (6) by per capita income $\left(Y_{t}\right)$ to obtain:

$$
\frac{P D_{i t}+P I_{i t} / P O P_{t}}{Y_{t}}=\frac{P D_{i t}+P I_{i t}}{G D P_{i t}}=
$$




$$
P C I_{i}=\left(\frac{\alpha_{i}}{Y_{t}}\right)+\beta_{i}+\delta_{i}\left(\frac{\operatorname{dev} Y_{t}}{Y_{t}}\right)
$$

The first variable on the right side of equation (8) is the inverse of per capita income, which measures the effect of permanent increases in per capita income on the composition of consumer demand. The second variable is an intercept term. The third variable measures the percentage deviation of per capita income from the long run trend in GDP in each period, capturing the impact of business cycle fluctuations on $P C I$.

\section{Net Exports}

The final component of steel consumption to be forecast is net exports. There are many determinants of international trade including current income levels in the trading countries, trade barriers, relative production costs, technology and productive efficiency. It is beyond the scope of this paper to investigate all of these potential influences on international trade. To keep the forecasting exercise manageable and minimise the data requirements, net exports are forecast using time trends similar to those used to forecast $M C P$.

\section{FORECASTS OF JAPANESE STEEL CONSUMPTION}

Apparent crude steel consumption data is available from the International Iron and Steel Institute (1998), however, this data is aggregated across all end-use industries and is inappropriate for this study. Fortunately, Consumption of Finished Steel Products by Uses data by major end-use industry (for domestically produced steel products) and Consumption of Imported Finished Steel Products by Product Type data (for imported steel products) is available from the Japan Iron and Steel Federation in The Monthly Report of the Iron and Steel Statistics (1998 and earlier issues).

The data contained in these two categories are combined to provide a measure of total domestic steel consumption from both domestic and imported sources for each steel consuming industry. The end-use industries included in this study are Machinery, Electrical Machinery and Equipment, Transport Equipment, Other Manufacturing, Construction and Fabricated Metal Products. All steel consumption data are allocated to 
at least one of these six industries. The sample period for this model is $1980-96$ since the data on industry output used to calculate $P C I$ are not available for 1997. Industry production data used in the calculation of the $P C I$ 's was obtained from the Nikkei database at the Australia National University. Steel consumption data for 1997 is available and can be used to check the accuracy of the model's forecasts. The forecast period is $1997-2005$.

\section{Forecasts of the Material Composition of Products}

The equations used to forecast $M C P$ are presented in Table 1. A logarithmic time trend was fitted for the Machinery, Electrical Machinery, Transport Equipment and Fabricated Metal Products industries. For the remaining industries, a linear time trend is used based on superior in-sample fit. Only the forecasts of $M C P$ for Transport and Construction are presented in Figures 4 and 5 since these two industries accounted for close to 80 percent of total steel consumption during the 1990 's.

\section{TABLE 1}

ESTIMATED EQUATIONS FOR THE MATERIAL COMPOSITION OF PRODUCTS

\begin{tabular}{lccccc}
\hline Industry & Const & Time & Inv/GDP & adj. $\mathrm{R}^{2}$ & $\mathrm{~F}$ \\
& & & & & \\
Machinery & $-0.065(0.5)$ & $-0.020(2.4)^{*}$ & $0.012(3.2)$ & 0.56 & 11.38 \\
Electrical Machinery & $0.376(46.4)$ & $-0.085(18.4)^{*}$ & & 0.95 & 337.59 \\
Transport Equipment & $1.468(39.6)$ & $-0.139(7.1)^{*}$ & & 0.72 & 42.98 \\
Other Manufacturing & $0.024(0.8)$ & $-0.001(3.3)$ & $0.002(2.5)$ & 0.46 & 8.02 \\
Construction & $0.157(0.5)$ & $-0.005(2.5)$ & $0.021(2.3)$ & 0.30 & 4.45 \\
Fab Metal Products & $1.867(33.1)$ & $-0.279(11.1)^{*}$ & & 0.86 & 99.78 \\
& & & & &
\end{tabular}

Figures in parantheses are heteroskedastic and autocorrelation consistent Newey-West $t$ statistics.

* Logarithmic time trend used. 
The negative coefficient on the time trend in all equations in Table 1 indicates that $M C P$ has been falling over the sample period, implying a reduction in steel consumption per unit of output in these industries. The two most obvious reasons for this trend is the effect of new steel saving technologies or material substitution away from steel towards newer materials. There is, however, a third possibility. Since $M C P$ is measured at the industry level, the declining trend could have also resulted from a change in the mix of goods being produced in that industry. So rather than existing goods becoming less steel intensive, new goods that use no steel could have been introduced into the industry. Of course it is difficult without more detailed data on steel consumption usage and the composition of output within each industry to establish what proportion of the decline in $M C P$ is attributable to each of these three possibilities.

FIGURE 4

FORECASTS OF THE MATERIAL COMPOSITION OF PRODUCTS FOR TRANSPORT EQUIPMENT

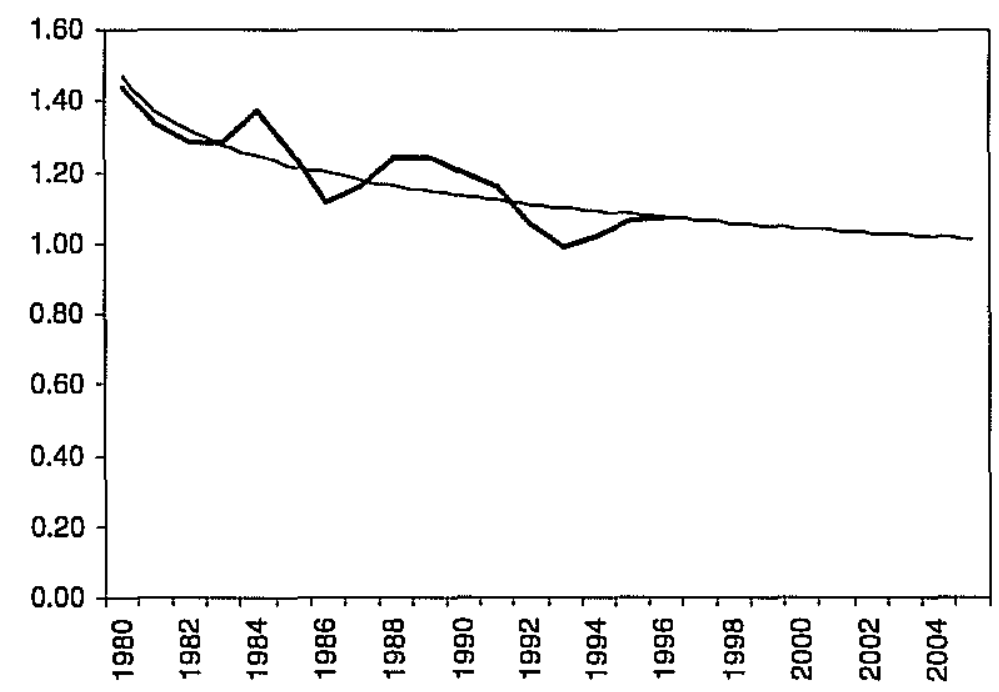




\section{FIGURE 5}

\section{FORECASTS OF THE MATERIAL COMPOSITION OF PRODUCTS FOR CONSTRUCTION}

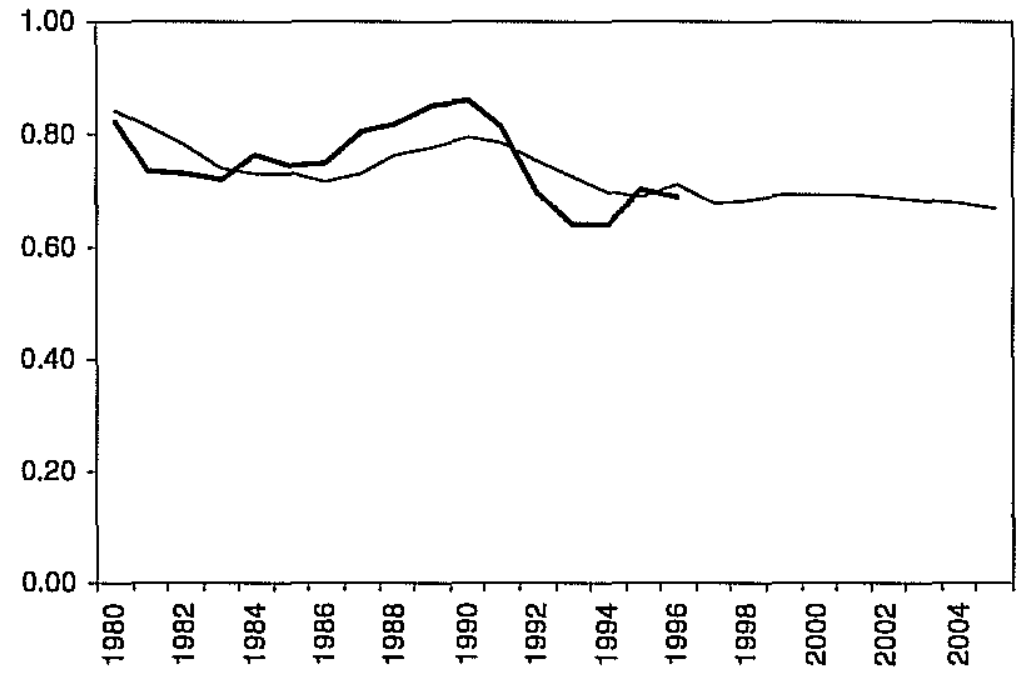

The time trends appear to fit the data remarkably well for the Electrical Machinery, Transport Equipment and Fabricated Metal Products industries. In these industries, the time trend explains at least 72 per cent of the variation in $M C P$. For the Machinery, Other Manufacturing and Construction industries, the time trends failed to capture much of the variation in MCP. The inclusion of the ratio of investment expenditure to GDP (Inv/GDP) in these equations, however, significantly improved explanatory power. The positive coefficient suggests that rises in Inv/GDP coincide with a higher $M C P$. This suggests higher levels of investment expenditure alter the composition of production within these industries towards steel intensive investment goods.

\section{Forecasts of the Product Composition of Income}

The estimates of equation (8) are presented in Table 2 . The actual and forecast values of $G D P$ and population, used to construct the variables $1 / Y_{t}$ and $\operatorname{dev} Y_{t}$, are presented in Table 4. The actual and forecast values of PCI for Transport and Construction are presented in Figures 6 and 7. 
In each equation, the variable $d e v Y_{t}$ was statistically significant at the 95 per cent level of confidence. In four of these equations, Machinery, Transport Equipment, Construction and Fabricated Metal Products, the coefficient on this variable was positive, indicating that purchases from these industries move pro-cyclically with business cycle fluctuations in per capita income. Hence, above average levels of per capita income will coincidence with a temporary expansion in purchases from these industries relative to $G D P$, but as income levels fall below the long run trend sales from these industries decline. In the equations for Electrical Machinery and Other Manufacturing, the coefficient on this variable was negative indicating that purchases from these industries temporarily decline relative to $G D P$ during a cyclical upturn in per capita income.

TABLE 2

\section{ESTIMATED EQUATIONS FOR THE PRODUCT COMPOSITION OF INCOME}

\begin{tabular}{lcccccc}
\hline Industry & Const & $\alpha_{\mathrm{i}} / \mathrm{Y}_{\mathrm{t}}$ & $\operatorname{dev} \mathrm{Y}_{\mathrm{t}}$ & Time & adj. $\mathrm{R}^{2}$ & $\mathrm{~F}$ \\
Machinery & & $109.7(74.5)$ & $0.094(8.9)$ & & 0.59 & 24.53 \\
Electrical Machinery & $0.164(11.2)$ & $-358.9(8.3)$ & $-0.084(2.4)$ & & 0.98 & 344.06 \\
Transport Equipment & $0.035(99.9)$ & & $0.062(9.0)$ & & 0.87 & 114.30 \\
Other Manufacturing & $0.044(77.3)$ & & $0.050(6.2)$ & & 0.64 & 29.43 \\
Construction & $-0.283(3.1)$ & $1030.4(4.4)$ & $0.466(4.9)$ & $0.005(3.5)$ & 0.63 & 9.94 \\
Fab Metal Products & $0.017(139.4)$ & & $0.015(8.4)$ & & 0.76 & 52.03 \\
& & & & & & \\
\hline
\end{tabular}

Figures in parantheses are heteroskedastic and autocorrelation consistent Newey-West $t$ statistics.

The coefficient on the inverse of per capita GDP was insignificant in the equations for Transport, Other Manufacturing and Fabricated Metal Products. This suggests that $P C I$ remained stable over the sample period apart from temporary variations caused by fluctuations in consumer spending, as indicated by the statistical significance of the $\operatorname{dev} Y_{t}$ variable. Alternately, these results suggest that changes in per capita income over the 
sample period have not significantly influenced the size of these industries relative to $G D P$.

FIGURE 6

FORECASTS OF THE PRODUCT COMPOSITION OF

INCOME FOR TRANSPORT EQUIPMENT

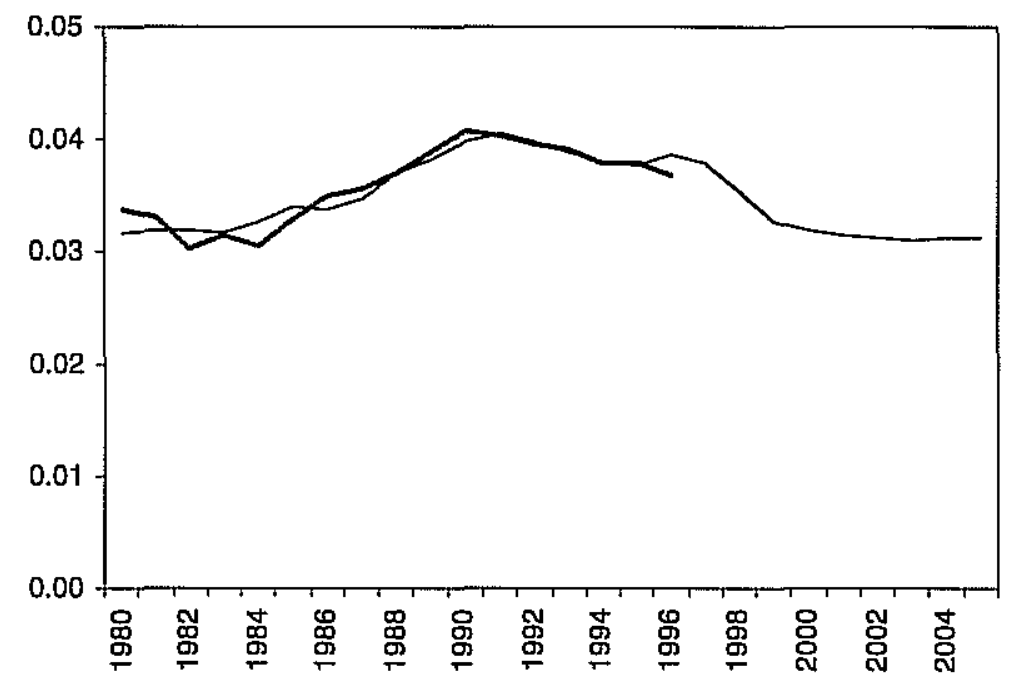

FIGURE 7

FORECASTS OF THE PRODUCT COMPOSITION OF

INCOME FOR CONSTRUCTION

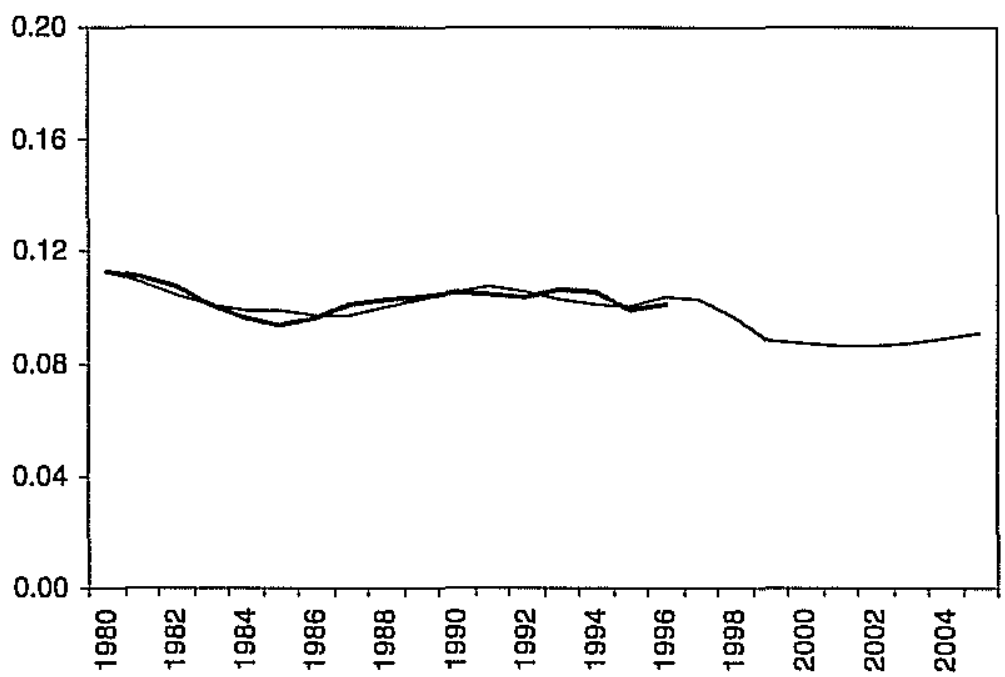


In the equations for Machinery, Electrical Machinery and Construction, both $1 / Y_{t}$ and $\operatorname{dev} Y_{t}$ are both statistically significant. This indicates that the relative size of these industries are influenced by both long run changes in per capita income and cyclical fluctuations in per capita income around the long run trend. Since it is the inverse of per capita income that has been included in the equations, the negative coefficient on this variable in the Electrical Machinery equation indicates that the relative size of this industry has increased with rises in per capita income. The positive coefficient on this variable in the Machinery and Construction equations indicates that the relative size of these industries has been falling.

It is interesting in Figures 6 and 7 that the $P C I$ of the Transport and Construction industries is forecast to fall significantly in 1998 and 1999, the two years of negative $G D P$ growth. This suggests that production in these industries will fall by a larger proportion than other industries. It is intuitive, given the durable nature of output from these industries, that consumption of output from these industries be delayed during periods of recession.

\section{Forecasts of Net Exports}

Table 3 contains the estimated equations for net exports. Only four equations are listed in Table 3, since there was no international trade in the Construction and Fabricated Metal Products industries over the sample period.

TABLE 3

ESTIMATED EQUATIONS FOR NET EXPORTS

\begin{tabular}{lcccc}
\hline Industry & Const & Time & adj. $\mathrm{R}^{2}$ & $\mathrm{~F}$ \\
Machinery & $944.5(5.05)$ & $827.5(9.8)^{*}$ & 0.91 & 170.47 \\
Electrical Machinery & $1489.4(16.2)$ & $404.5(11.8)^{*}$ & 0.77 & 54.40 \\
Transport Equipment & $3959.2(10.7)$ & $-20.7(2.6)$ & 0.04 & 0.74 \\
Other Manufacturing & $5008.3(9.1)$ & $-176.6(3.7)$ & 0.61 & 25.68 \\
& & & & \\
\hline
\end{tabular}

Figures in parantheses are heteroskedastic and autocorrelation consistent Newey-West $t$ statistics.

* Logarithmic time trend used. 
As mentioned previously, time trends were used to forecast net exports in each industry for simplicity. Obviously, the ability of these equations to explain variations in net exports maybe improved by the inclusion of macroeconomic variables such as the exchange rate and income levels, for both Japan and Japan's main trading partners. Several of these variables were tested in the net exports equations, yet they added relatively little explanatory power in this instance and if included in the final equation, forecasts of these variables would be required also. Based upon the apparent lack of explanatory power of these macroeconomic variables this complication is unwarranted.

\section{Forecasts of Gross Domestic Product}

The final component of equation (4) is gross domestic product. The GDP growth rates used to forecast steel consumption are presented in Table 4. Even though the forecast period commences from 1997 onwards, actual GDP and population data are available from the IMF (1998 and earlier issues) to 1997. Forecasts of population are required to calculate the per capita income variables used to forecast $P C I$. The population growth rate to 2005 is an arithmetic average of the actual population growth rate in Japan during the 1990's. 


\begin{tabular}{|c|c|c|c|c|}
\hline \multicolumn{5}{|c|}{ TABLE 4} \\
\hline \multicolumn{5}{|c|}{$\begin{array}{c}\text { GROSS DOMESTIC PRODUCT AND POPULATION } \\
\text { FORECASTS }\end{array}$} \\
\hline & GDP & GDP growth & Population & Population growth \\
\hline & (billions of yen) & (\%) & (millions) & $(\%)$ \\
\hline 1990 & 430040 & 4.82 & 123.54 & 0.34 \\
\hline 1991 & 446371 & 3.80 & 123.92 & 0.31 \\
\hline 1992 & 450981 & 1.03 & 124.32 & 0.32 \\
\hline 1993 & 452339 & 0.30 & 124.67 & 0.28 \\
\hline 1994 & 455254 & 0.64 & 124.96 & 0.23 \\
\hline 1995 & 461951 & 1.47 & 125.20 & 0.19 \\
\hline 1996 & 480073 & 3.92 & 125.76 & 0.45 \\
\hline 1997 & 484379 & 0.90 & 126.13 & 0.30 \\
\hline 1998 & 474691 & -2.00 & 126.51 & 0.30 \\
\hline 1999 & 463299 & -2.40 & 126.88 & 0.30 \\
\hline 2000 & 467005 & 0.80 & 127.26 & 0.30 \\
\hline 2001 & 472609 & 1.20 & 127.64 & 0.30 \\
\hline 2002 & 480171 & 1.60 & 128.02 & 0.30 \\
\hline 2003 & 487854 & 1.60 & 128.40 & 0.30 \\
\hline 2004 & 497611 & 2.00 & 128.78 & 0.30 \\
\hline 2005 & 507563 & 2.00 & 129.17 & 0.30 \\
\hline
\end{tabular}

Finished Steel Products Consumption to 2005

Combining the forecasts of the four components of steel consumption according to equation (4) provides forecasts of aggregate steel consumption across all six steel consuming industries. These forecasts are measured in terms of tonnes of finished steel products and are presented in Appendix A. Columns 1 to 6 of Table A1 list the forecast values of Finished Steel Products Consumption for each of the six industries. Column 7 lists forecasts of steel products consumed as Rolling Stocks. The forecast of this category is calculated as the arithmetic average of the 1995-97 figures. The forecasts of steel consumption for each industry can be compared directly to the actual industry steel consumption data over the period 1980-97 in columns 9 to 15 of Table A1. 


\section{Converting Finished Steel Products to Crude Steel}

The conversion of finished steel products consumption to crude steel equivalent appears in Table 5. Column (1) contains the forecasts of finished steel products consumption constructed using equation (4), while column (2) contains the actual values from the Japan Iron and Steel Federation (1998 and earlier issues).

Column (3) is the conversion rate of actual crude steel consumption to actual finished steel products consumption and is obtained by dividing column (2) by column (5). In 1980, for example, one tonne of crude steel yielded 0.707 tonnes of finished steel products. Forecasts of this conversion rate over the period 1998-2005 are calculated as the arithmetic mean of the actual conversion rates from 1987 to 1997. The forecasts of crude steel consumption in column (4) from 1997 onwards are calculated by dividing the forecast of finished steel products consumption by the conversion rate. Column (5) contains actual crude steel consumption data from the International Iron and Steel Institute (1998 and earlier issues).

The forecasts suggest that crude steel consumption will rise in 1997, before falling in each year from 1998 to 2001 . In the final four years of the forecast period steel consumption is forecast to rise marginally. The main cause of the decline in steel consumption from 1998 is the impact of negative growth in GDP and sharp declines in $P C I$ (for all industries apart from the $P C I$ for Electrical Machinery) during 1998 and 1999. The forecast decline in the Transport and Construction industries, Japan's two largest steel consumers, is particularly pronounced. When combined with a declining $M C P$, this negative growth is forecast to produce large reductions in crude steel consumption. In 2000, GDP growth is forecast to rise again by 0.8 per cent, yet steel consumption is still forecast to fall due to a continuation of the decline in $M C P$ and $P C I$. 
TABLE 5

FORECASTS OF CRUDE STEEL CONSUMPTION

\begin{tabular}{|c|c|c|c|c|c|}
\hline & \multicolumn{2}{|c|}{$\begin{array}{l}\text { Finished Steel Products } \\
\text { Consumption }\end{array}$} & \multirow[b]{2}{*}{$\begin{array}{l}\text { Conversion } \\
\text { Rate }\end{array}$} & \multicolumn{2}{|c|}{$\begin{array}{c}\text { Crude Steel } \\
\text { Consumption }\end{array}$} \\
\hline & Forecast & Actual & & Forecast & Actual \\
\hline 1980 & 64376 & 62941 & 0.797 & 80808 & 79007 \\
\hline 1981 & 61955 & 58510 & 0.823 & 75325 & 71136 \\
\hline 1982 & 59940 & 57321 & 0.825 & 72679 & 69504 \\
\hline 1983 & 57367 & 56530 & 0.862 & 66585 & 65614 \\
\hline 1984 & 58527 & 61908 & 0.832 & 70306 & 74367 \\
\hline 1985 & 61156 & 61869 & 0.843 & 72531 & 73377 \\
\hline 1986 & 60563 & 59655 & 0.853 & 71005 & 69941 \\
\hline 1987 & 63393 & 67468 & 0.891 & 71176 & 75751 \\
\hline 1988 & 70771 & 76062 & 0.876 & 80828 & 86871 \\
\hline 1989 & 75654 & 82843 & 0.888 & 85183 & 93278 \\
\hline 1990 & 81440 & 87685 & 0.885 & 91978 & 99032 \\
\hline 1991 & 84663 & 86577 & 0.873 & 96959 & 99151 \\
\hline 1992 & 81580 & 75160 & 0.894 & 91218 & 84040 \\
\hline 1993 & 77809 & 70685 & 0.877 & 88712 & 80589 \\
\hline 1994 & 74905 & 71569 & 0.902 & 83031 & 79333 \\
\hline 1995 & 74530 & 74308 & 0.881 & 84592 & 84340 \\
\hline 1996 & 80197 & 75643 & 0.905 & 88646 & 83612 \\
\hline 1997 & 77388 & 76101 & 0.885 & 87459 & 86004 \\
\hline 1998 & 71832 & & 0.887 & 80984 & \\
\hline 1999 & 65531 & & 0.887 & 73879 & \\
\hline 2000 & 64674 & & 0.887 & 72913 & \\
\hline 2001 & 64455 & & 0.887 & 72666 & \\
\hline 2002 & 64796 & & 0.887 & 73051 & \\
\hline 2003 & 65214 & & 0.887 & 73521 & \\
\hline 2004 & 66461 & & 0.887 & 74928 & \\
\hline 2005 & 67814 & & 0.887 & 76453 & \\
\hline
\end{tabular}

\section{CONCLUSION}

This paper uses the intensity of use technique to model and forecast crude steel consumption in Japan. The results suggest that the fall in consumption from 99 million tonnes in 1990 to 86 million tonnes in 1997, was primarily the result of a sharp fall in steel intensity, however, slower $G D P$ growth was also a contributing factor. Furthermore, the reduction in steel intensity was the result of new technologies, material substitution 
and changes in the composition of domestic production, all being factors which are unlikely to be reversed.

The forecasts of steel consumption from 1997 to 2005 were constructed separately across six steel consuming industries. The results of this study suggest that crude steel consumption in Japan will decline in each year from 1998 to 2002, before rising marginally in each year to 2005. The largest reductions in consumption are forecast to occur in 1998 and 1999, due primarily to the negative growth in GDP expected in these years. Throughout the forecast period, $M C P$ and $P C I$ are expected to decline in all industries (apart from $P C I$ for Electrical Machinery), leading to further reductions in steel intensity. Under conditions of declining steel intensity, steel consumption can only rise if positive GDP growth is able to counteract the negative effects of reductions in steel intensity on consumption.

The forecasts presented in this study assume that the volatility in $M C P$ witnessed during the late 1980's and early 1990's is not repeated during the forecast period. As mentioned previously, movements in $M C P$ appear to be highly correlated with the level of investment expenditure. Since the ratio of investment expenditure to GDP is assumed to remain relatively constant over the forecast period, the model is unable to capture changes in consumption arising from sharp movements in $M C P$. Expectations of any changes in investment expenditure, therefore, should be used to adjust the forecasts of crude steel consumption presented in this study accordingly. 


\section{Appendix A FORECASTS OF FINISHED STEEL PRODUCTS CONSUMPTION}

\section{TABLE A1 FORECASTS OF FINISHED STEEL PRODUCTS CONSUMPTION BY INDUSTRY}

Forecasts of Finished Steel Products Consumption

\begin{tabular}{cccccccc}
\hline $\begin{array}{c}\text { Mach } \\
(1)\end{array}$ & $\begin{array}{c}\text { E Mach } \\
(2)\end{array}$ & $\begin{array}{c}\text { Trans } \\
(3)\end{array}$ & $\begin{array}{c}\text { Manu } \\
(4)\end{array}$ & $\begin{array}{c}\text { Cons } \\
(5)\end{array}$ & $\begin{array}{c}\text { FMP } \\
(6)\end{array}$ & $\begin{array}{c}\text { Stocks } \\
(7)\end{array}$ & $\begin{array}{l}\text { TOTAL } \\
(8)\end{array}$ \\
3989 & 3028 & 19137 & 1757 & 27356 & 8959 & 149 & 64376 \\
3881 & 3063 & 18419 & 1726 & 26392 & 8353 & 122 & 61955 \\
3698 & 3131 & 18037 & 1678 & 25258 & 8035 & 102 & 59940 \\
3377 & 3195 & 17716 & 1592 & 23602 & 7802 & 82 & 57367 \\
3453 & 3366 & 18139 & 1626 & 23966 & 7892 & 85 & 58527 \\
3645 & 3578 & 18951 & 1696 & 25076 & 8144 & 65 & 61156 \\
3544 & 3652 & 18940 & 1671 & 24611 & 8088 & 56 & 60563 \\
3809 & 3811 & 19599 & 1756 & 26068 & 8291 & 59 & 63393 \\
4513 & 4085 & 21226 & 1973 & 30044 & 8852 & 76 & 70771 \\
4938 & 4272 & 22336 & 2105 & 32709 & 9217 & 77 & 75654 \\
5442 & 4462 & 23598 & 2258 & 35968 & 9633 & 79 & 81440 \\
5608 & 4591 & 24480 & 2315 & 37685 & 9908 & 76 & 84663 \\
5150 & 4561 & 24079 & 2185 & 35824 & 9730 & 51 & 81580 \\
4702 & 4494 & 23359 & 2049 & 33712 & 9445 & 49 & 77809 \\
4333 & 4450 & 22839 & 1936 & 32067 & 9236 & 45 & 74905 \\
4237 & 4449 & 22747 & 1902 & 31969 & 9180 & 45 & 74530 \\
4724 & 4567 & 23784 & 2044 & 35512 & 9519 & 47 & 80197 \\
4307 & 4533 & 23415 & 1919 & 33794 & 9374 & 46 & 77388 \\
4009 & 4359 & 21610 & 1802 & 31258 & 8749 & 46 & 71832 \\
3656 & 4178 & 19656 & 1671 & 28239 & 8086 & 46 & 65531 \\
3588 & 4147 & 19269 & 1642 & 28030 & 7953 & 46 & 64674 \\
3541 & 4132 & 19081 & 1622 & 28144 & 7888 & 46 & 64455 \\
3502 & 4133 & 19093 & 1607 & 28526 & 7891 & 46 & 64796 \\
3464 & 4131 & 19116 & 1591 & 28966 & 7898 & 46 & 65214 \\
3472 & 4144 & 19346 & 1591 & 29888 & 7974 & 46 & 66461 \\
3483 & 4153 & 19593 & 1591 & 30894 & 8054 & 46 & 67814
\end{tabular}

Finished Steel Products Consumption

\begin{tabular}{|c|c|c|c|c|c|c|c|c|}
\hline & $\begin{array}{c}\text { Mach } \\
\text { (9) }\end{array}$ & $\begin{array}{c}\text { E Mach } \\
(10)\end{array}$ & $\begin{array}{c}\text { Trans } \\
\text { (11) }\end{array}$ & $\begin{array}{c}\text { Manu } \\
\text { (12) }\end{array}$ & $\begin{array}{l}\text { Cons } \\
\text { (13) }\end{array}$ & $\begin{array}{c}\text { FMP } \\
\text { (14) }\end{array}$ & $\begin{array}{l}\text { Stocks } \\
(15)\end{array}$ & $\begin{array}{l}\text { TOTAL } \\
\text { (16) }\end{array}$ \\
\hline 1980 & 4238 & 3212 & 18288 & 1678 & 26750 & 8625 & 149 & 62941 \\
\hline 1981 & 3810 & 2938 & 17923 & 1557 & 24215 & 7944 & 122 & 58510 \\
\hline 1982 & 3595 & 3082 & 17049 & 1727 & 24053 & 7714 & 102 & 57321 \\
\hline 1983 & 3167 & 3121 & 17578 & 1642 & 22979 & 7962 & 82 & 56530 \\
\hline 1984 & 3602 & 3690 & 20015 & 1765 & 24111 & 8641 & 85 & 61908 \\
\hline 1985 & 3549 & 3549 & 20280 & 1701 & 24184 & 8541 & 65 & 61869 \\
\hline 1986 & 3098 & 3301 & 18310 & 1522 & 25406 & 7963 & 56 & 59655 \\
\hline 1987 & 3834 & 3732 & 19595 & 1846 & 29893 & 8509 & 59 & 67468 \\
\hline 1988 & 4632 & 4454 & 22247 & 2116 & 33036 & 9501 & 76 & 76062 \\
\hline 1989 & 5263 & 4833 & 24405 & 2361 & 36072 & 9833 & 77 & 82843 \\
\hline 1990 & 5674 & 4920 & 25447 & 2361 & 39079 & 10126 & 79 & 87685 \\
\hline 1991 & 5500 & 5311 & 25495 & 2309 & 37992 & 9894 & 76 & 86577 \\
\hline 1992 & 4448 & 4108 & 23279 & 1917 & 32589 & 8768 & 51 & 75160 \\
\hline 1993 & 4223 & 3879 & 21500 & 1859 & 30775 & 8399 & 49 & 70685 \\
\hline 1994 & 4483 & 3941 & 21305 & 1925 & 30742 & 9129 & 45 & 71569 \\
\hline 1995 & 4769 & 4297 & 21941 & 2017 & 32269 & 8970 & 45 & 74308 \\
\hline 1996 & 4995 & 4197 & 22142 & 1916 & 33036 & 9309 & 47 & 75643 \\
\hline 1997 & 5050 & 4418 & 22804 & 1924 & 32539 & 9320 & 46 & 76101 \\
\hline
\end{tabular}

Note: Columns 1 to 6 and 9 to 14 are Machinery, Electrical Machinery and Equipment, Transport Equipment, Other Manufacturing, Construction and Fabricated Metal Products 


\section{REFERENCES}

Chen, D., Clements, K.W., Roberts, E.J. and Weber, E.J. (1991), 'Forecasting Steel Demand in China', Resources Policy, 17(3), pp.196-210.

Crompton, P.L. (1998), Forecasting Steel Demand in South-East Asia, Department of Economics, University of Western Australia, Discussion Paper 98.05.

International Iron and Steel Institute (1987), Steel Statistical Yearbook, Committee on Economic Studies, ISI, Brussels.

International Monetary Fund, (1998), International Financial Statistics, IMF, Washington.

Japan Iron and Steel Federation, (1998), Monthly Report of the Iron and Steel Statistics, JISF, Tokyo.

Labson, S., Gooday, P. and Manson, A. (1995), China Steel, ABARE Research Report 95.4, Canberra.

Roberts, M.C. (1990), 'Predicting metal consumption: The case of US steel', Resources Policy, 16(1), pp.56-73.

Tcha, M. (1998), 'Intensity of steel use and environments in Southeast Asia', in Wu, Y. (ed), The Economics of the East Asia Steel Industries, Ashgate, Aldershot.

Tilton, J.E. (1990), The OECD Countries: Demand Trend Setters', in Tilton, J.E. (ed), World Metal Demand: Trends and Prospects, Resources for the Future, Washington, D.C.

Wu, Y. (1998), 'China's Metals Industry', in Wu, Y. (ed), The Economics of the East Asia Steel Industries, Ashgate, Aldershot. 